\title{
Pattern of Social Skills Education Based on Religious Character at Islamic Boarding School Al-Hikmah 2
}

\author{
M.Khanif Yusman ${ }^{1}$, Joko Widodo ${ }^{2}$, Rusdarti ${ }^{3}$, Juhadi $^{4}$ \\ \{hanifyusman4@gmail.com¹,jk-wido@yahoo.co.id ${ }^{2}$, rusdarti@gmail.com ${ }^{3}$, \\ juhadi.geo86@gmail.com ${ }^{4}$ \}
}

\begin{abstract}
Student of Social Sciences Education Study Program, Universitas Negeri Semarang, Indonesia ${ }^{1}$ Department of Economics, Faculty of Economics, Universitas Negeri Semarang, Indonesia ${ }^{2}$ Department of Economics, Faculty of Economics, Universitas Negeri Semarang, Indonesia ${ }^{3}$ Department of Geography, Faculty of Social Sciences, Universitas Negeri Semarang, Indonesia ${ }^{4}$
\end{abstract}

\begin{abstract}
The inability of humans to preserve nature which results in various environmental damage requires educational efforts through the development of social skills based on character. This study aims to examine educational patterns in shaping social skills based on religious character in Islamic Boarding School Al-Hikmah 2. This research uses qualitative techniques. Data analysis consists of gathering, reducing, presenting, and conclusions. The results showed that the pattern of education included the vision which provided the basis for social skills based on character development; the mission is to uphold in the creed, be true in worship, be noble in behavior, foster community life, and preserve Islamic values, have a soul of sacrifice, a spirit of religion, and flexible. The purpose of education is to produce students who are fiddin, mutadayyin, and muta'addib. The conclusion is the model of social skills based on religious character looks at the vision, mission, goals, and principles.
\end{abstract}

Keywords: Islamic Boarding School, Religious Character, Social Skills.

\section{Introduction}

Environmental damage caused by the inability of humans to manage nature and the surrounding environment has become one of the serious problems in the last decade both on a global and national scale [1]. Low awareness of behavior and knowledge encourages the need for efforts to make people aware of the benefits of environmental conservation. Therefore we need an education system that teaches theory and applies direct behavior in the field as a form of implementing education. Environmental damage in the form of landslides, floods, rob, abrasion, forest fires, forest clearing, and the presence of vacant land. Failure in the social environment in the form of behavior patterns of lack of responsibility, dirty words, dishonest, unable to communicate, littering, and lack of mutual respect. 


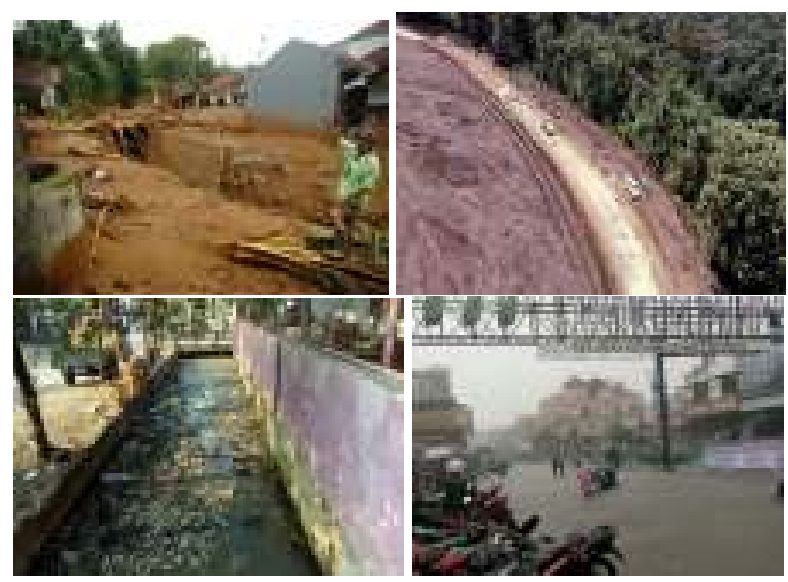

Fig. 1.Environmental Damge in Brebes.

The failure of efforts to preserve the environment for the achievement of the goals of national education, led to the emergence of ideas about character education to realize the Indonesian people as a whole who hold fast to religious and social values. Minister of National Education M. Nuh emphasized on National Education Day on May 2, 2011 that character-based education was used as a national movement, including non-formal and informal education. Character is a description of a person's thoughts, values, words, and actions [2]. According to the Minister of Education the character is built on the character of glory as a nation. The birth of character education is an attempt to revive the ideal-spiritual pedagogic lost by the wave of positivism spearheaded by the French philosopher Auguste, character will shape motivation, and at the same time be formed with dignified methods and processes. Character is not just an outward appearance, but it implicitly reveals hidden things. Therefore people define care and action based on ethical values, including cognitive, emotional, and behavioral aspects of moral life. The right education in Indonesia is "value-based education" [3]. There are 18 character values embedded in character education according to the Ministry of National Education (2010), one of which is religious. There are four types of characters that are applied in the education process, namely character education based on religious cultural values, the environment, and self-potential. Most of Indonesian people who still make religion (religious values) as a guide to social life encourage the application of education that forms the character based on religious values. The results of the study [4] showed that the majority of teachers and students believed that religious practices and values had an impact on student regularity and reduced dropout rates.

Character education that is based on religion is education that develops values based on religion that shape personal, attitudes, and behavior that are primary or noble in life. The family and school environment are expected to prioritize character education [5]. In Islam, character education has similarities with moral education. The term morality has been entered in the Indonesian language, which is moral. Moral (in Arabic: al-akhlak) according to Ahmad Muhammad Al-Hufy in "Min Akhlak al Nabiy", is "strong azimah (willingness) about something that is done repeatedly so that it becomes customary (entrenched) which leads to goodness or badness ". Therefore, the terms "noble or good morals" (al-karimah morals) and "bad morals" (al-akyuq al-syuu) are introduced. The teachings about morals in Islam are important as the 
teachings on aqeedah (belief), worship, and mu'amalah (society). Prophet Muhammad S.A.W, was sent to perfect human morals, "innamaa buitstu li-utannima padaarim al-akhlak". Enhancing human morals means increasing morals that are already good and eroding bad morals so that they are lost and replaced by noble morals. This is the glory of human life as God's main creature. The results of the study [6] indicate that the curriculum of the Prophet's biography can be used for the development of social intelligence.

Islamic boarding school is the right place to facilitate the education of values needed by the community. The education of character values taught in Islamic boarding schools is more optimal compared to other educational institutions because it can be directly practiced in daily life in pesantren and becomes a habit of santri life [7]. Islamic boarding school is the oldest educational institution in Indonesia, which existed before the birth of the modern education system. Several pesantren have been established and act as important and flexible institutions in being actively involved as institutions that are close to the community around the pesantren [8]. Islamic boarding schools have a strategic position in educating the character of the next generation of Muslims who are friendly and care for the surrounding environment. In this case pesantren is an independent, non-governmental Islamic educational institution that can make important contributions to the environment. Character education in Islamic boarding schools can be useful for resolving conflicts [9]. This institution is a place to educate students cadres who are expected to be able to answer the challenges of the need for religious knowledge which includes knowledge about the environment [10]. Islamic Boarding Schools as educational institutions have a better role to increase the effectiveness of social development of students through academic programmers and training [11]. Communication skills and thinking styles have a significant correlation with teacher performance [12] so it is expected to have an impact on the social development of students. In addition, pesantren has become a concern of the world community because it can be considered as a node of cultural encounter and cultural broker (cultural broker) for the flow of ideas of modernization from the city [13].

An Islamic boarding school is basically a traditional Islamic education dormitory where students live together and study religious sciences under the guidance of a teacher known as a Kyai. The students' dormitory is in the Islamic boarding school complex. In addition there are also worship facilities in the form of mosques. [14] defines that Islamic boarding school is a traditional Islamic educational institution to study, understand, explore, live, and practice Islamic teachings by emphasizing the importance of religious morals as guidelines for daily behavior. The existence of Islamic boarding schools in the midst of the community has a role and function as a place of introduction and understanding of Islam as well as a center for the spread of Islam. Most boarding schools are established as a form of reaction to certain life patterns that are considered vulnerable, thus the establishment of boarding schools becomes one part of cultural transformation that runs in a relatively long period of time because the nature of Islamic boarding school as a starting point for transformation, by itself Islamic boarding school are forced by circumstances to obtain the best alternative for life. Islamic boarding school as an ideal choice is in accordance with the culture of Islam in Indonesia. Even though Islamic boarding school are considered as traditional educational institutions, it does not mean that Islamic boarding school do not experience changes and adjustments. Islamic boarding school has become part of the life system of most Muslims in Indonesia and has undergone changes over time in accordance with the life journey of the ummah. Changes that occur in Islamic 
boarding school are the result of dialogue with the era so that Islamic boarding school as an educational institution also has a system like other educational institutions.

Based on the description above, the purpose of this study is to examine the pattern of social skills education based on character in Islamic Boarding School Al-Hikmah 2 Benda. The expected benefits can contribute thoughts for the development of social science education in general, and relating to social skills based on character values in Islamic boarding schools in particular.

\section{Method}

This research uses descriptive qualitative method with the object of research Islamic Boarding School Al-Hikmah 2 Benda Village, Sirampog District, Brebes Regency. The data collection of this research uses purposive sampling technique, that is data obtained from sources based on subjects who know, understand, and experience directly in the development and implementation of the application of religious-based character education system in Islamic Boarding School Al-Hikmah 2 Benda consisting of coaches, caregivers, administrators, cleric and santri. Data collection techniques in this study were carried out by means of observation, questionnaires, interviews, and documentation. Data analysis in this study consisted of data collection, data reduction, data presentation, and drawing conclusions

\section{Results and Discussion}

Some findings in the study are Islamic Boarding School Al-Hikmah 2 to develop an organized, systematic and integrated program between potential sources and targets to be achieved through the division of pioneering periods, growth and development periods. The application of the functions and roles of Islamic boarding school activities are included in the Tri Dharma of Islamic Boarding Schools, namely faith and piety towards Allah SWT; development of useful knowledge; and devotion to religion, society and the state. As for running the education system can be known from the vision, goals and principles of Islamic boarding school. An explanation of the pattern of education in Islamic Boarding School Al-Hikmah 2 is explained as follows.

Islamic Boarding School Al-Hikmah 2 has a vision of "Becoming a Islamic Boarding School that provides a foundation in the development of the education, teaching and propaganda system". Alignment of the two potentials that are packaged and applied in deeds (Da'wah), or in other words, the harmony and synergy between the behavior of ritual worship and actual or social worship so as to achieve the goal of a life that is safe for the world and the hereafter [15]. This vision is a form of developing social skills based on religious values, namely Ta'aawanuu 'alalbirriwattaqwaa (please help in kindness and devotion). The concept of the goodness and piety of Islam in the QS. Al-Imran verses 2-3 based on the translation (Ministry of Religion, 2015) as follows "Goodness is all actions based on faith (firm belief in Allah SWT accompanied by submission and submission of souls in other words faith is carried out by dhikr and thinking) ; devotion is an endeavor to guard against God's torture by following His commands and 
avoiding His prohibitions. " The concept of Ta'aawanuu 'alalbirriwattaqwaa (please help in goodness and devotion) is the same as an attempt to align the goodness of education and teaching (dhikr and thinking) with dakwah (endeavor). Thus the vision of the Islamic Boarding School which is to provide a foundation in the development of the education system, teaching, and preaching is the harmony of the two potentials (dhikr and thinking) which are packaged and applied in an action (endeavor) together with the implementation of the Ta'aawanuu 'alalbirriwattaqwaa concept.

The mission of Islamic Boarding School Al-Hikmah 2 is directed at efforts to prepare human resources that are upright in creed, correct in worship and noble behavior, fostering healthy community life, so as to be able to develop and preserve Islamic values, support the national development process through the provision of human resources that have a soul of sacrifice, religious enthusiasm, and flexible attitude. This educational mission requires the provision of education, training, cadre training, guidance, guidance and development of Islamic propaganda that is solutive in work and achievement. The mission shows that the Islamic Boarding School Al-Hikmah 2 develops a character-based educational system and is similar to other Islamic boarding schools based on religious values as stated [14] states that "the boarding school principle is theocentric". Theocentric principle requires students to have the right intention (seeking knowledge); choose the right knowledge, teacher and study partner; respect for science and teachers; have perseverance, sincerity and strong ideals; determine learning material and its size (gradual according to ability); surrender (tawakal) and keep from something unclean. The mission of Islamic Boarding School Al-Hikmah 2 is related to the development of solutive Islamic da'wah containing the meaning of rahman and rahim. Rahman rahim is the forming of social relations [16]. The formation of Islamic values in social relations is part of a missionary missionary education that is solutive. According to him, this is the same as amar ma'ruf and nahi munkar. Amar ma'ruf and nahi munkar are interpreted as an effort to encourage people to do good, after the person concerned does so he is called upon to increase these good deeds. So those who advocate the good must be able to position themselves as pioneers, not giving instructions. On the other hand, evil forehead is directed at efforts to take preventive measures, which also start from every member of the community. Everything was done on the basis of awareness and sincerity [16].

The purpose of Islamic Boarding School Al-Hikmah 2 is to produce students who are fiddin, mutadayyin, and muta'addib with the purpose of a Muslim with social skills because one of the features of fiddin, mutadayyin, and muta'addib students is rahman rahim with sincerity. Rahman rahim with sincerity is a characteristic of social skills. Social skills based on religious character values are born because they always act rahman rahim which is sourced from the deepest voice of the bati (human nature given by Allah SWT). This is evident in the purpose of Islamic Boarding School Al-Hikmah 2 in carrying out all its activities because it is aimed at worshiping Allah SWT. Evidence of the purpose of worship, one of which lies in the purpose of establishing Islamic boarding schools who print true-faith people. People who have true aqeedah will live istiqomah / stand firm / consistent in worship. The purpose of Islamic Boarding School AlHikmah 2 is the same as the goal of Islamic education in Islamic boarding schools and in line with the aim of National Education according to Law No. 2 of 2003 article 4 which states "National Education aims to educate the life of the nation and develop Indonesian people as a whole, namely human beings who believe and devoted to God Almighty and noble character, having knowledge and skills, physical and spiritual health, a steady and independent personality 
and sense of community and national responsibility ". Based on the objectives of national education, it appears that what is intended is part of the Islamic Boarding School Al-Hikmah 2 Education objective, namely that students have noble character as an implementation of the heights of the teachings of Rosulullah SAW to their people.

Islamic Boarding School Al-Hikmah 2 applies the principles of effective and efficient education in the educational process to realize educational goals. This is reflected in the seriousness in developing the social skills of the students including direct involvement in order to be able to do something and be beneficial to the people, fostering the character of the people at every level of society, applying existing concepts to the reality of life and life, fostering the power of innovation and achievement; and the implementation of teaching and education is carried out continuously and continuously [17].

Social science education (PIPS) in Indonesia has a vision as forming personality attitudes and behavior of students to become good and responsible citizens who can distinguish rights and obligations in the context of moral ethics in the life of families, communities, nations and countries. The vision of PIPS in Indonesia is the same as the vision of Islamic Boarding School Al-Hikmah 2 Benda, namely the balance of education, teaching and preaching. PIPS mission is to instill education in values, morals, ethics, virtuous attitudes, and devotion to God Almighty. In addition, the PIPS mission is for students to become good citizens, and be able to solve social problems they face in their daily lives based on Pancasila and the 1945 Constitution [18]. The mission is the same as the mission of the Islamic Boarding School Al-Hikmah 2. This is due to the efforts in organizing education in Al-Hikmah 2 Benda are more contextual because they produce students who understand religious knowledge (faqih fiddin), have strong religion (mutadiyin), and have good manners in behavior (muta'adib). This mission is realized through training, regeneration, coaching, and coaching to solve environmental problems both natural damage and poverty that are directed in the development of Islamic propaganda that is solutive in work and achievement.

The vision and mission of PIPS is in accordance with the aim of Islamic education which is to give birth to a servant of God who has the merciful nature of his fellow man. If it is converted with PIPS's goal that is educated in values, morals, ethics, and virtuous lies in the character of being simple and not arrogant, good words and diligent worship and devotion to God Almighty. The nature of such servants generally always remembers the hereafter, does not worship other than Allah (the One God), and always respects Allah. The attitude of being a good citizen as above is the same as the nature expected by Islam which is not fake, open, not wasteful, and not stingy, able to solve the social problems it faces in daily life according to the nature of ibadurrahman (QS Al- Furqon verses 63-71). The vision, mission and goals of the PIPS for a Muslim will succeed because it is a gift. The gift is obtained as a reward from the qualities of perfection and noble character / character thanks to patience and perseverance in carrying out God's commands and avoiding God's prohibitions. By carrying out all the commands and avoiding His prohibitions, a Muslim believes that all problems can be solved properly. That is due to the belief that God will help him.

Based on the formation of attitudes in the context of moral ethics on the vision and mission of PIPS above, it is clear that there is a link between the goals of national education and social studies teaching and the objectives of Islamic education, namely the formation of the concept of humanity from the value of religious character. The humanitarian concept of the value of religious character is a central element in the lessons in force in Indonesia today. The character 
of the Indonesian people who often combine the values of religious characters with local culture makes it not in conflict with the values of religious characters (Islam) as long as these cultures will enrich the treasures of the values of religious characters. The role of PIPS in the inculcation of values and cultural education as one of the educational programs essentially as cultural education is interpreted as a program supporting a cultural institution that plays a role in the acculturation and enculturation process of cultural support to support it is part of PIPS. The majority of Indonesian people are Muslim and the culture that is already attached to their people is also based on the teachings of the Islamic religion, the Islamic boarding school is a concrete manifestation of the institution that develops its members to attach the teachings of the religious character values (Islamic religion) in daily life. Thus social skills based on Islamic boarding schools are social skills that are based on Islamic values that are in harmony with local culture are part of the objectives of PIPS.

\section{Conclusion}

Based on the results of research, in general, sensitivity to the environment is successfully realized if education is carried out using social skills based on religious characters by functioning of the khalifah fil ardi (user, engineer and preserver of the universe with all its contents in accordance with tauhid uluhiyah). In particular, Islamic Boarding School AlHikmah 2 managed to score students who care about the environment through the application of social skills based on religious character values or ta'aawanu 'alalbirriwattaqwaa. Religious character-based social skills models appear in educational patterns that include the vision, mission, goals and principles of Islamic Boarding School Al-Hikmah 2.

Acknowledment, Thank you to KH. Sholahudin, S, Ag. as the leader of the Islamic Boarding School Foundation Al-Hikmah 2 Benda Sirampog Brebes who has given a research permit, as well as all parties who have helped the research process until the manuscript is completed. 


\section{Reference}

[1] Keraf, A.S. Etika Lingkungan. Buku Kompas, Jakarta (2002)

[2] Jais, S.M., Yatim, A.A., Arip, M.A.S.M. Prodigy: An Innovative Approach For Character Development. Jurnal Pendidikan Karakter. pp. 240-247 (2012)

[3] Sumaatmadja. Pengantar kearah Pendidikan Lingkungan. FKIS. IKIP, Bandung (1979)

[4] Ali, M.A., Rathore, F., \& Siddique, D. The Impact of Religious Practices and Values on Academic Achievements of Students at Secondary Level. Journal of Education and Practice. pp. 38-43 (2019)

[5] Saidek, A.R., Islami, R., \& Abdoludin. Character Issues: Reality Character Problems and Solutions through Education in Indonesia. Journal of Education and Practice. pp. 158-165 (2016)

[6] Al-Khateeb, O. \& Alrub, M.A. The effectiveness of the curriculum Biography of the Prophet in the development of social intelligence skills of Al-Hussein Bin Talal University Students. Journal of Education and Practice. pp. 83-97 (2015)

[7] Asue, D.U. \& Kajo, D. Pedagogy of Christian Religious Education in Nigerian Schools. Journal of Education and Practice. pp. 37-49 (2018)

[8] Mangunjaya, F. M. Ekopesantren Bagaimana Merancang Pesantren Ramah Lingkungan?. Yayasan Obor Indonesia, Jakarta (2014)

[9] Alqahtani, R.M. The Effectiveness of Goldstein's Social Skillstreaming Model on Social Skills of Special Education Pre-Service Teachers at Najran University. Journal of Social Science Studies. pp.149-159 (2016)

[10] Aygun, H.E., \& Taskin, C.S. Teachers' Views of Social-Emotional Skills and Their Perspectives on Social-Emotional Learning Programs. Journal of Education and Practice. pp. 205-215 (2017)

[11] Damirchi, E.S. The Impact of Social-Emotional Learning Skills Programs on Social Development Among Primary School Students. Journal of Education and Practice. pp. 202-207 (2013)

[12] Moghtaderi, H. \& Aziz, R.G.G. The Relationship Between Communication Skills and Managers' Thinking Style Functions with the Job Performance of Elementary School Teachers in Urmia, Iran in The Academic Year 2018-2019. European Journal of Education Studies. pp. 103-115 (2019)

[13] Fathoni, A. Metodologi Penelitian dan Teknik Penyususnan Skripsi. Rineka Cipta, Jakarta (2006)

[14] Mastuhu. Dinamika Sistem Pendidikan Pesantren. INIS, Jakarta (1994)

[15] Asrori, A. Islamic Education Philosophy Development (Study Analysis on Ta'lim al-Kitab alZarnuji Muta'allim Works). Journal of Education and Practice. pp. 74-81 (2016)

[16] Jalaludin, R. Psikologi Komunikasi. Remaja Rosdakarya, Bandung (2003)

[17] Mudawarulfalah. Strategi Pemberdayaan Santri dan Masyarakat di Pondok Pesantren Al-ittifaq.

PPs UNINUS, Bandung (2006)

[18] Hamid, D. Pengantar Pendidikan Kewarganegaraan. Alfabeta, Bandung (2010) 